\title{
DOGS AND LIONS IN THE ORESTEIA
}

\section{F. Saayman, University of the North}

Most studies of Aeschylean imagery have made simple deductions as to its meaning, whereby a single motif is encapsulated in what may be called a monistic abstraction. Thus Whallon interprets the vulture and eagle symbolism as "predacity" (1961:81); likewise Lawrence takes all the animal imagery together as displaying "the predatory laws of nature" (1976:107). In the case of " $\operatorname{dog}^{\prime}$ and "lion" imagery in the Oresteia this is an oversimplification which leads to wrong interpretations of some occurrences. Such single labels for imagery are obtained in a facile manner by accepting the most direct meaning common to all the instances and linking it to some assumed aspect of an imagined semiotic background. When applied to the text, we can simply state repeatedly that certain imagery portray the same idea over and over, such as "predatory justice", as if this is the only meaning of all its occurrences. Instead, the imagery should rather be interpreted in terms of its function in the play (Garson 1983:33). In the case of "dog" and "lion" imagery, subdivisions in the imagery serve not only to bind the three plays together and to show contrast between and within characters, but it also forms an integral part of the literary contrast in the major theme of predeterminism versus personal responsibility, providing crucial insight into the psychology of the characters.

Both the hound and lion images function as positive images when used of the war against Troy, and both become perverted when functioning in the family theme. In the family theme the dog image depicts external motivation, in contrast to character; the latter being associated with the lion image. The lion image itself splits into crimes due to character, and crimes against each other between members of the same family.

\section{HOUNDS AND WATCHDOGS: INDICATOR OF EXTERNAL MOTIVATION}

The first instance of the hound image is intertwined with bird imagery ("winged hounds of the father" - $A g .136$ ), and to see it in its perspective of thematic perversion, which means that the initial favourable meaning later changes to an unfavourable meaning, one must start with the associated bird imagery. The bird imagery starts with the vulture simile, in which the bereaved parent vultures serve as symbol for the Greeks after the loss of Helen. Zeus hears them and, like sending an Erinys, sends the Atreidae to punish Paris (Ag. 4962). The bird image therefore depicts righteous revenge on Troy, and the Atreidae are acting as just agents of Zeus and are incarnations of the idea of an Erinys. Erinys, bird and justified revenge by Agamemnon are thus linked to one another. In the Choephoroi the bird image again depicts loss. When Orestes asks Zeus' help he calls himself and Electra

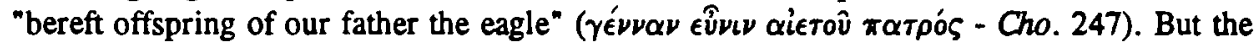
notion of loss and justified revenge against Troy, as represented by the birds, undergoes an awful perversion when the birds of prey are metaphorically identified with hounds in

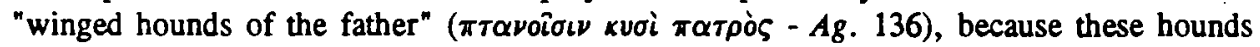
are, at this location, symbols of the Erinyes preying on the family of the Atreidae. The omen at Aulis and its interpretation contains a multitude of images and twists. The eagles devouring the hare are propitious for the expedition against Troy (Ag. 104), but Artemis is angry at them and in a transition from their function in the Trojan theme to their function in the family theme they change to "winged hounds of the father", an image which is later taken up again when Orestes avenges his own father, spurred on by the dogs of his father 
(see Erinyes as dogs, below). The attitude of Artemis brings metaphors together in a syllogism. In the first part Artemis is angry at the winged dogs (metaphor for the eagles) for killing the hare and, in the second part, she is kind to all the weak, suckling young of lions and animals that roam the field (Ag. 140-143). The two attitudes are expressed in such a way that together they form a syllogism: In the first part, strong, adult animals kill weak, small ones. In the second part, the weak animals are the children of the strong ones. The implication is therefore that the strong adults kill their own weak children, a clear reference to the Thyestes meal, when Atreus served Thyestes' own children to him. Thus both the hound and the lion, as parts of the syllogism, become linked to the Thyestes meal. Moreover, with the allusions to the Thyestes meal firmly established, the piece ends with

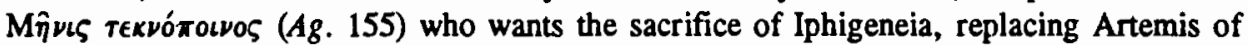
the Trojan theme with the family history as the reason for the sacrifice. The syllogism's allusions to parent-child conflict in the family textually motivate the role of the Menis, who must be involved because of the Thyestes meal. In other words, Menis is acting as if she is a guardian of the family curse. At this stage both the dog and lion images are linked to the Thyestes meal and seemingly to the family curse in the family theme.

The hound, as image of a just cause against Troy, is continued in xvvo yoi (Ag. 694) where

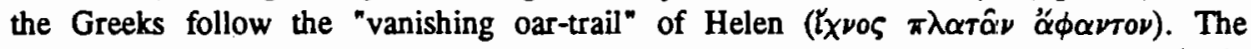
revenge is this time linked to Menis, because she sent Helen to Troy as a problem (I I iw

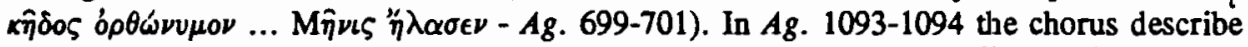

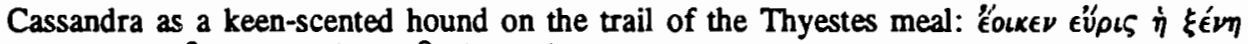

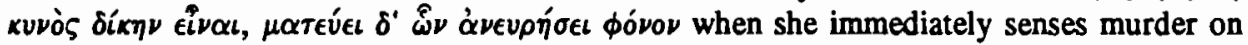
hearing that she is at the house of the Atreidai. She proceeds to mention all the crimes in the house, explicitly linking the crimes to the house again when she sfes a vision of the slain children (of Thyestes) sitting on the house (Ag. 1217-1219). Avengers on the trail in the family theme occur again in Eum. 245ff. when the Erinyes get the scent trail of Orestes

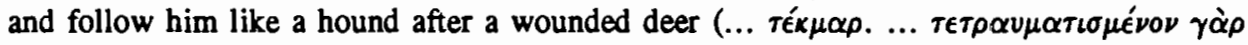

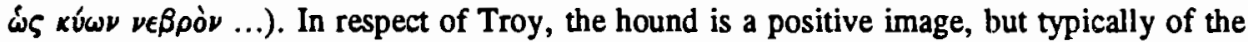
Oresteia it becomes perverted in the family theme, linked to filial murder. Moreover, it is

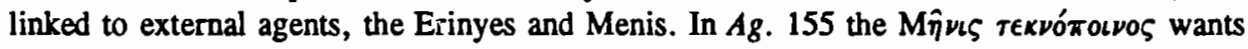
the sacrifice of Iphigeneia as atonement for the Thyestes meal, thus functioning as a personification of the family curse which Aigisthus says, in Ag. 1600-1602, that Thyestes pronounced on Atreus and his descendants. Thus in terms of the family theme, which originates with the Thyestes meal, the hound image is associated with divine personifications of the family curse.

The watchdog image changes in the same way. In the prologue the watchman on the palace roof lies with his chin on his arms, "like a dog", watching for the sign of Agamemnon's

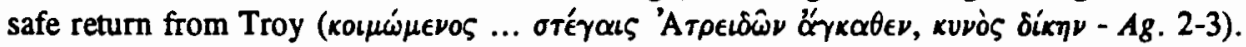
Again the house is mentioned explicitly. But Clytaemestra, pretending to be Agamemnon's

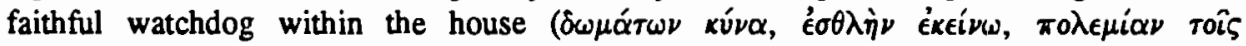

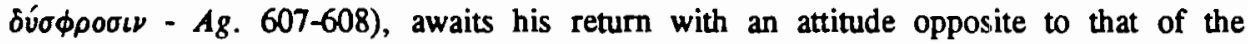
watchman on the roof, plotting Agamemnon's death. Again crime is associated with the house.

Clytaemestra emphasizes the relation between crime and the house when she welcomes Agamemnon by handing over to him the task of watching over the house and calling him

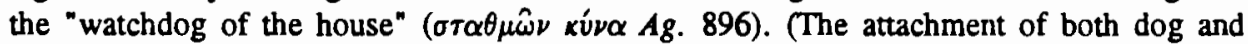
lion images to the house, as suggestions of predeterminism versus personal motivation, will be taken up again further on.) But Cassandra, who knows the past and future, later calls Clytaemestra a "hateful dog ... with beaming dispostion ... like treacherous Ate"

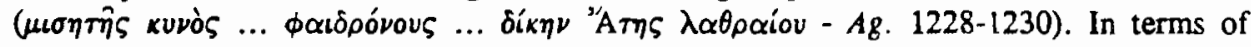


motifs this is an oxymoron, because, while "dog" is part of the theme of external motivation, "beaming" recalls the "beaming face" of the lion-cub in the lion simile (Ag. 725), which is a symbol for personal responsibility, as will be shown further on. The oxymoron is proleptic of a dichotomy in Clytaemestra's motivation, which will unfold further around the murder scene. Clytaemestra likes to play the innocent instrument of external forces, but here is the first hint that she is personally responsible. In respect of the "beaming face" of the lion-cub in the lion simile (Ag. 725), which was in the service of Ate (Ag. 735-6), a careful distinction should be made between Ate on the one hand and the Erinyes and Menis on the other. As used in the lion simile, Ate means "Destruction", while in other contexts it is an entity like the Erinyes and Menis. Ate in the lion simile thus does not imply a connection between the lion image and predeterministic forces.

The development from watchdog to revenge as applied to Clytaemestra is repeated in reverse sequence when applied to Orestes and Electra. After the murder the chorus predicts revenge for Agamemnon's murder, namely that "some assisting avenger will spring forth

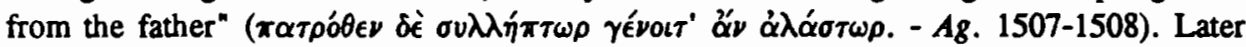
Orestes links up with this "assisting avenger" when he wants to avenge his father's death

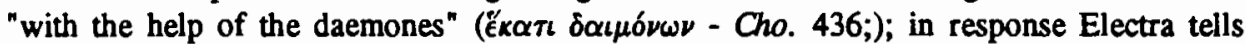

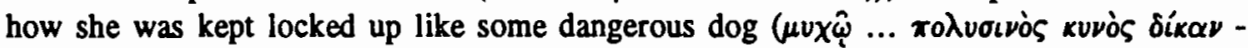
Cho. 447). The two of them are thereby united as a pair of avengers, in an identification process between daemon and dog which is the reverse of that of Clytaemestra. The reference to the "house" in $\mu v \times \hat{\omega}$ continues the suggestion of crimes connected to the house, here, in the context of "dog" imagery, suggesting that the crimes are the result of a curse clinging to the house.

\section{ERINYES AS DOGS}

The previous association between dogs and the Erinyes changes to identification of the two in the second half of the Oresteia. The hidden plotting of the watchdog (Clytaemestra) and the locked up dogs (her children) is replaced here by a return to the hound image. When Orestes is about to kill his mother, she warns him beforehand that the dogs of vengeance

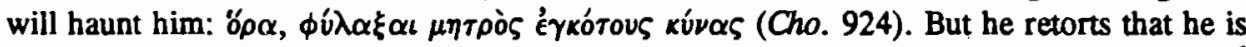
avenging his father's death, spurred on by the hounds of vengeance of his father: $\tau \dot{\alpha} \varsigma \tau \hat{\jmath}$

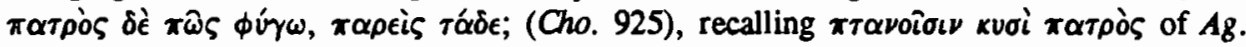
136. After the deed Orestes indeed sees the hounds that must avenge his crime on his

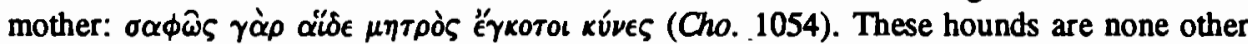
than the Erinyes. In the Eumenides Clytaemestra chides the Erinyes because "Tis but in a dream thou art hunting thy game, and art whimpering like a hound that never leaves off its keenness for the chase" (Eum. 131-132, Loeb). When they get on his trail it is like a dog

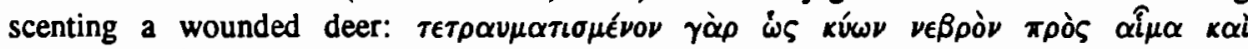

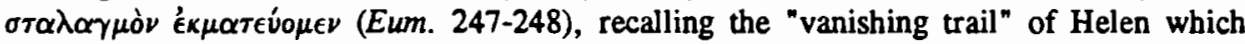
the Greeks openly followed. The hound therefore, is not as sly and deceitful as the watchdog.

\section{LION: INDICATOR OF CHARACTER}

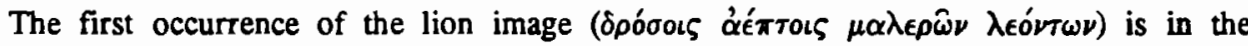
syllogism of Ag. 135-143 (above), where it is implied that the parents in the Pelopidae family eat their children and Mîvı revenge for the Thyestes meal. But at the start of the omen there are other aspects of the lion image. The Greek army will destroy even the cattle of Troy $(A, 128)$, proleptic of 
Agememnon's association of the army with the lion image in Ag. 827 (below). Trojan cattle become thematically linked to the sheep killed in the lion simile and to Clytaemestra's accusation of Agamemnon for killing his daughter while there is an abundance of sheep for the house (Ag. 1416-1417). The killing of cattle at Troy and the lion's killing of sheep both lead up to the guilt of Agamemnon for sacrificing Iphigeneia instead of some of his sheep.

Another aspect of the animal imagery in the interpretation of the omen is revealed in the words "two Atreidae, different in disposition/character" of Ag. 123-124, which Calchas sees in the two eagles. This is proleptic of the lion simile's ascribing of crime to character instead of to divine causation. It therefore stands in direct opposition to the Menis at the end of the omen section as the cause of Iphigeneia's sacrifice, where Menis is involved in the filial murder by the lion in the syllogism. The omen section and the lion simile serve as two opposing anchor points in respect of the interpretation of the lion image.

Anne Lebeck interpreted the lion simile as indicating hereditary guilt. She thus deducss that "imagery drawn from the lion parable is used to describe every figure in the Orestei? who acts as an instrument of the Erinys" (1971:50). As far as the Erinys is concerned this has been shown to be true only of the dog image, not of the lion image. Knox correctly sees the simile as meaning that "in each generation the evil strain in the race comes out" (1952:22). But he makes no connection between "evil strain in the race" and character. Rather he sees the "repetitive pattern imposed on the lives of Pelops' descendants by the system of private vengeance" as a curse, which may be seen as a predeterministic interpretation (1952:24). Perradotto showed the correct meaning, namely that ultimately the simile ascribes crime to character. He sums it up concisely: "The lion-cub ..., despite a $\tau \rho \circ \phi \eta$ calculated to alter its natural character, ultimately displays its inherited disposition of savagery ..." (1969:256), which is applicable to the "evil strain in the race" (Knox, above). Perradotto correctly interprets the lines after the simile as deeds linked to character and not to external divine intervention. The child having the same character as the parent, is not exactly the same as a curse predetermining action. The two notions represent the two opposing ethical issues of the trilogy, namely predestination by a curse versus motivation by character. The song in which the lion simile occurs, starts with the crime of Paris, develops to the lion simile, and is then ultimately applied to Agamemnon's crime of sacrificing Iphigeneia. It implies that he did not kill her because of the Thyestes meal or a divine force associated with it, such as the Menis mentioned with the omen, but because of some inherited character trait, an "evil strain in the race". Thus the lion image is associated with character and personal responsibility, while, as shown above, dog images are associated with external forces of predeterminism, namely Menis or the Erinyes. Agamemnon is furthermore linked to the lion by crossed opposition between the lion and himself. While we expect the lion to kill the people of the house, it kills "sheep"! Conversely Clytaemestra accuses Agamemnon of killing his daughter instead of some of the sheep which they own (Ag. 1416-1417).

Up to this stage the lion image has been used only in connection with the family theme, and not with Agamemnon as conqueror of Troy, except for the proleptic allusion in $x \tau^{\prime} i \eta$ in the omen. The $\dot{\omega} \mu \eta \sigma \tau \dot{\zeta} \varsigma \lambda \epsilon^{\prime} \omega \nu$ of $A g .827$ need not be seen as primarily portraying Agamemnon's excess at Troy, but rather as a positive statement in the Trojan theme, as part of the perversion pattern, such as the perversion of $x \tau$ in meaning in the Trojan theme to its later link with references to Iphigeneia's death. Agamemnon takes pride in the association with the lion image, because this is in answer to the previous criticism of the chorus ( $A g .799-802)$ that they thought he was wrong going to war for the sake of Helen. Significantly, their criticism does not include the sacrifice of 
Iphigeneia. He explains that "we have exacted payment for a presumptuous robbery, and for a woman's sake ..." (Fraenkel's translation). (The co-ordinate clause should, however, not be interpreted as additive, but as content, namely describing the robbery.) In terms of competitive values Agamemnon felt an obligation to exact vengeance for theft. He takes the lion image as a positive symbol of justified revenge, just as the chorus in Cho. 938 apply it to Orestes when he avenges his father's death. But by associating himself with the lion image, Agamemnon ironically links himself to the syllogism - he is a child-slayer. Now we can understand why the chorus did not mention Iphigeneia - because the intention of the text here is to allude to her through the Trojan theme. If Knox (1952:20) is correct in following Headlam and the description by Pausanias of the chest of Cypselus, that the lion was the badge of the Lydian dynasty of Pelops, then the lion image in the Oresteia has much more to do with the Pelopidae family than with the same image used against Troy in the Iliad. One must therefore be careful of interpreting the wholesale destruction of Troy as excessive or wrong, because Agamemnon is already as guilty as he needs to be, as a child-slayer.

With regard to the slaying of Trojan children, the conduct in war-time of certain people in Africa until recently might serve as a comparison. Several instances are known from history where children were killed along with their parents. The reason for doing this has also not yet died completely, namely that the children ought to be killed lest they take revenge later when they have grown up. This perhaps provides an interesting insight into the purpose of the detailed description of the slaying of Trojan children. While Agamemnon took this precaution in terms of his competitive values, Clytaemestra and Aigisthus made the mistake of not killing Agamemnon's children, thus allowing them to grow up and take vengeance (cf. above, on Orestes and Electra as dogs of vengeance). The same custom applies to the Jewish invasion of Biblical Canaan. Lawrence therefore rightfully warns against bringing in "a kind of Euripidean humanity in order to conclude that the gods object to the carnage" (1976:103). Against Troy the lion image is therefore positive, but against the family it becomes perverted and negative.

The next instance of the lion image is when it is used for Aigisthus. Scholars agree that the lion stands for every character who commits a crime (Lebeck 1971:50, Knox 1952:18), but they have never applied it satisfactorily to Aigisthus and Clytaemestra. Thus Knox (1952:20) does not take its application to Aigisthus seriously, but regards it simply as sarcasm, only employing the fact that Clytaemestra also took him into the house. No mention is made of his character being responsible for his crime.

Cassandra sees visions of slain children sitting on the house, after which she says that "for this reason ... some powerless lion, wallowing in the bed, a stay-at-home, is plotting" ( $\mathrm{Ag}$. 1223-1224, Fraenkel). Obviously both the bed and house are those of Agamemnon. Applied to Aigisthus, the lion image implies that this adultery is a self-motivated crime, and as such is in contrast to the motivation by the Thyestes meal to murder Agamemnon. The lion, as image of self-motivated crime, is linked directly to Aigisthus' adultery with the wife of Agamemnon, which is, significantly, a repetition of the crime of his father against the father of Agamemnon. Aigisthus thus reverts in this way to his own inherited character, just like the lion cub. The lion image is used in a similar derogatory way when

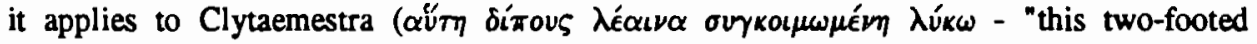
lioness sleeping with a wolf" - Ag. 1258), both instances in contrast with Agamemnon as a

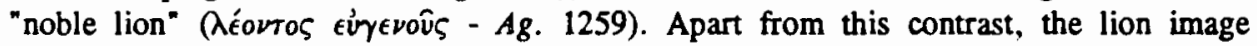
connects Clytaemestra to personal responsibility, because the image is used in exactly the same context as it was used of Aigisthus, namely that she is committing adultery with Aigisthus! 
Thus both Clytaemestra and Aigisthus are called lions only when their adultery is exposed, a crime which belongs to the category of personal responsibility. But Clytaemestra has also previously been linked to the lion image, as a "fawning watchdog" (Ag. 1228-1230, above), with reference to her treachery. Thus the lion image goes beyond her adultery, and makes it a personal reason to murder her husband.

The reference to filial murder in the lion image, established in the syllogism in the omen's interpretation, compounded by the aspect of character in the lion simile, also makes Agamemnon personally guilty in the same section where Aigisthus is called a lion, with

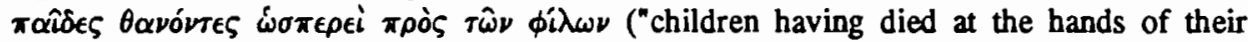
family" - Ag. 1219), which refers back to the syllogism's allusion that the strong slay their own children. In the Choephoroi filial murder and personal responsibility is applied to Orestes by the lion image. After Orestes had taken his mother into the house to kill her (and later Aigisthus), the chorus refer to Orestes and Pylades as "a twofold lion" ( $\delta\llcorner\pi \lambda \circ \hat{\sigma} \varsigma$ $\lambda \hat{e} \omega \nu$ - Cho. 938). The lion has now become a child killing parents, bringing to fulfilment

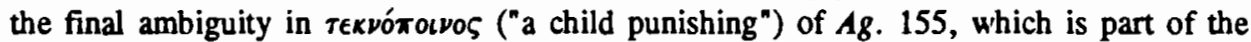
context in which the syllogism gave the sinister meaning to the first occurrence of the lion image. As a lion, Orestes is personally motivated, in contrast to being motivated externally by Apollo.

When the lion occurs for the last time (Eum. 193-195), Apollo chides the Erinyes, saying that they should retreat from the company of men and should stay in "the den of some blood-lapping lion" (Loeb). This is the only association between the Erinyes and lions, and since it differs in this respect from the lion motif, is no longer part of the motif. But the chorus of Erinyes express a last echo of filial murder, linking the syllogism and the lion

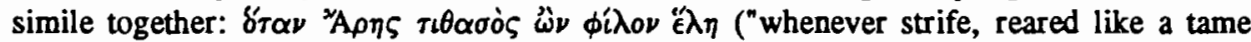
beast, attacks its own" - Eum. 355-356, Lebeck 51).

\section{CONTRAST BETWEEN EXTERNAL AND INTERNAL MOTTVATION}

Although the imagery and motifs run through the whole trilogy, they play an important part in the unravelling of the $\alpha \nu \alpha \gamma \nu \dot{\alpha} \rho \iota \sigma \iota s$ of the first drama, namely in Clytaemestra's defence and in connection with the house and family.

After the murder Clytaemestra unwittingly becomes involved in a debate with the chorus about external or personal reasons for the murder. She links herself via Ate to the family

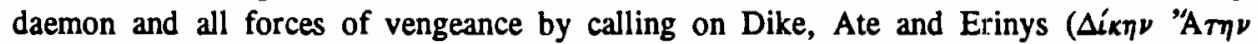
'Esıv'v $\theta$ ' Ag. 1432-1433), trying to excuse herself by putting the ultimate blame on external predeterminism. Her defence contains ringcompositional elernents: Initially she

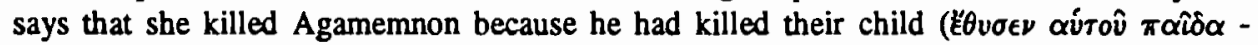
Ag. 1417), a crime aggravated by the fact that he sacrificed their child "while sheep abound" ( $\left.\mu \eta^{\prime} \lambda \omega \nu \phi \lambda \in{ }^{\prime} v T \omega \nu ~ A g .1416\right)$. This recalls the cattle of Troy in the omen and the slaughter of sheep in the lion simile, thus bringing in the lion image, the motif of personal responsibility resting on character. At this stage, however, Ciytaemestra herself has also been identified with the lion image (the treacherously fawning watchdog, and her adultery), so that this excuse explodes in her face. The implication is thus that she really killed Agamemnon as the only way to get away with her adultery with Aigisthus. But as the chorus blame a daemon, the personification of the curse (Ag. 1468 and 1481-1482), Clytaemestra, either sarcastically or inanely, changes her position completely and identifies herself with this daemon in $\mathrm{Ag}$. 1476-1477 and 1500-1503, as taking revenge not only for Iphigeneia's death, but also for the Thyestes meal: taking vengeance on Atreus she has

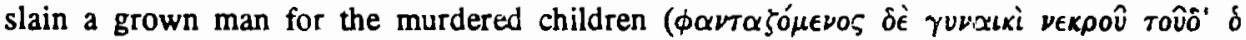

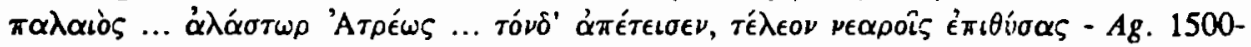


1504). In Ag. 1525-1526 she again blames Agamemnon for killing Iphigeneia, returning in a ringcompositional fashion to her first motivation. The ringcomposition poses two excluding alternatives. Did she kill Agamemnon on her own motivation because he deserved it, or are they both innocent victims in the hands of external forces? While she finds a handy excuse in external forces, the connection between the lion image here and herself hints that she also acts according to her character, which, unfortunately for her, provides no excuse. The revenge which she had planned as deceitful watchdog is thus contrasted with the personally inspired crime of the lion image.

In the discussion of dog imagery (above), the association of the dog imagery with the "house", was pointed out. But other animals are also connected to the house: The eagles of the omen appear "ixr $\alpha \rho \mu \epsilon \lambda \alpha \dot{\theta} \theta \omega \nu$ ("near to the abode" - Ag. 116 (Fraenkel)) and are transformed into the dogs and lions of the syllogism. The lion simile starts with: $E \theta \rho \in \downarrow \in \nu$

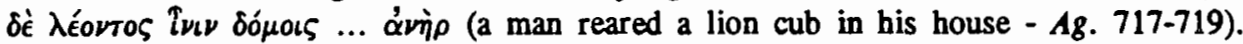

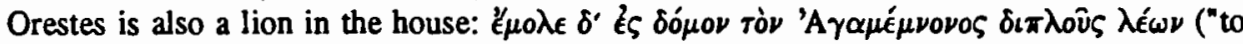
the house of Agamemnon came a twofold lion" - Cho. 937-938). When Orestes kills his mother, the chorus rejoice that the house has been saved (Cho. 942-943). Linked to the dog imagery and its association with the Erinyes, the "house" theme is part of the notion of a curse clinging to the house. Linked to the lion imagery, the "house" theme is part of the notion of a criminal characteristic which typifies a particular strain or character trait in the family living in the house.

This brings us to a most interesting part of the text. In Ag. 1565-1566, after the mention of the curse in the altercation between the chorus and Clytaemestra (above), the chorus say:

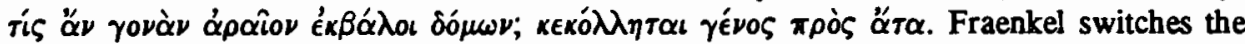

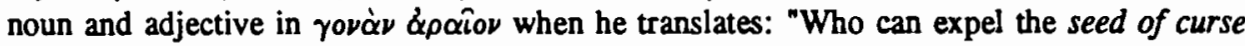
from the house? The race is glued fast to perdition." (My emphasis.) This rendering

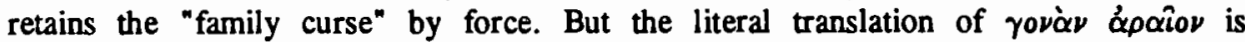

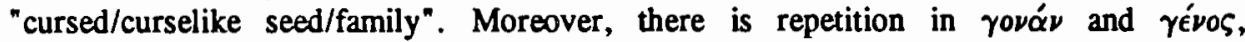
suggesting a similarity between the two sentences. This choice of expression is not merely a syntactical variation: it is a deliberate ambiguity, because Aeschylus usually hides his allusions behind the literal meanings of ambiguous words. Fraenkel simply missed the allusion. If we adjust the other meaning of yovó $\nu$, namely "a race", "family", to

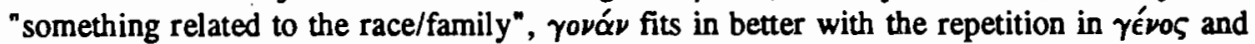
gives a meaning which fits in with the second sentence: "Who can expel the cursed family strain from the house". The family is glued to crime." (Cf. Knox's "evil strain" in connection with the lion simile, above.) This rendering brings the lion and dog imagery and its attachment to the house to a solution, namely that crime is linked to innate character. It is therefore a direct demythologizing of the family curse idea, replacing it with character.

Such an interpretation is in line with Knox's observation on the lion simile (above), that the lion cub is a symbol of how in the family of Pelops "in each generation the evil strain in the race comes out" (1952:22). Despite Dover's (1973:60) and Lloyd-Jones' (1956:64) unconvincing complaints in this regard, this author agrees with Perradotto $(1969: 257,261)$ that character replaces external coercion in the Oresteia, in line with Heraclitus'

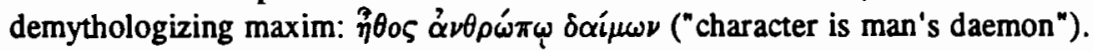

Instead of labelling all animal imagery with a single interpretation of "predatory justice", a distinction between hound, watchdog and lion imagery reveals contrasts that are functional in the trilogy. These contrasts are linked to both the basic ethical issues, as well as to the psychology of the characters. 


\section{BIBLIOGRAPHY}

Dover, K.J. 1973. "Some neglected aspects of Agamemnon's dilemma." JHS XLIII, 5869.

Fraenkel, E. 1950. Aeschylus, Agamemnon. Oxford: Clarendon Press.

Garson, R.W. 1983. "Observations on some recurrent metaphors in Aesthylus' Oresteia." AC XXVI, 33-39.

Knox, B.M.W. 1952. "The lion in the house." CPh XLVII, 17-25.

Lawrence, S.E. 1976. "Artemis in the Agamemnon." AJPh 97, 97-110.

Lebeck, A. 1971. The Oresteia: a study in language and structure. Cambridge: Harvard University Press.

Lloyd-Jones, H. 1956. "Zeus in Aeschylus." JHS LXXVI, 55-67.

Perradotto, J.J. 1969. "The Omen of the Eagles and the $\eta \theta 0 \varsigma$ of Agamemnon." Phoenix $23,237-263$.

Smyth, H.W. and Lloyd-Jones, H. 1963. Aeschylus II. Loeb series. London: Heineman.

Whallon, W. 1961. "Why is Artemis angry?" AJPh 82, 78-88.

\section{ACKNOWLEDGEMENT}

All word searches were done on the electronic text provided by the TLG project. 